\title{
The Party's dead, but the party goes on
}

The Soviet Academy of Sciences was replaced last week by a Russian academy, which want a prolongation of the past. But the future of the academy will hang on what funds, if any, the Russian government can afford.

\section{Moscow}

THE Soviet Academy of Sciences went out of business on Tuesday last week, when its president, Guri Marchuk, delivered with unaccustomed emotion the "last speech of the last president of the Soviet Academy".

Marchuk was addressing more than 1,000 people assembled in the great hall of Moscow State University not so much to listen to his account of the past as to draft the charter of the new Russian Academy of Sciences which Mr Boris Yeltsin, the president of Russia, has decreed will succeed the Soviet academy.

His audience was drawn from the 250 members of the old academy (the 'academicians'), its corresponding members, the 150 people elected to an unofficial Russian Academy of Sciences before Yeltsin made his play to take over the bigger fish and representatives of the old academy's research institutes, elected to have a say at the meeting. What the last group said in public was depressingly syndicalist.

Marchuk, by uncanny coincidence, was speaking just a day after the presidents of Russia, the Ukraine and Byelorussia had consigned the Soviet Union itself to limbo by declaring at Minsk that they will in future be members of a commonwealth of their own (and not Mr Mikhail Gorbachev's) design. Perhaps for the first time in six years (Marchuk has been in office for a month more than Gorbachev), the two men were in the same boat, confronted by the reclamation of the instruments of their power by lower orders in the hierarchy.

This is how Marchuk, a cautious and uncommunicative but, only partly for those reasons, an unpopular president of the Soviet academy, described last Tuesday's proceedings: "We have gathered not only to witness, but to participate in, a performance; many of you will share my opinion that it is not just a performance, but a tragedy".

The tragedy? The dismemberment of Soviet science. The performance? The formal enactment of the fashion for "democratization". But "scientific truth cannot be found by voting, so that the search for it must be in some sense undemocratic". Marchuk offered Lysenko as typifying the "people's academicians" whose emergence he feared.

The Soviet academy, Marchuck said, may have made mistakes, but he forecast that the new Russian academy will be a battleground for the "three major forces" that have fought over the corpse of the old academy. First, there are the gradualists such as himself. "Unfortunately, we lacked insight, skill and strength of mind. We were too dependent on those in power; we trusted their good intentions and their understanding of national problems. Posterity will justly accuse us, and will be right."

Second, there are the radicals (with the "ideological support of the press"). "They probably sincerely believe" that they can recreate Western science in Russia, but "that is a thistle that best grows on ruins, and will not yield crops". They will come to be recognized as the "destroyers of our country's science".

And the third force? The silent majority. "I appeal to you", Marchuk declared, to appreciate where "the processes started with your often passive participation" are leading, but "they are not yet irreversible". And will the Russian successor academy be able to overcome the "inevitable disappointments and losses" that lie ahead? "I believe we shall."

Marchuk, when he came to sit down, appeared as startled as his audience by what must have been the first full-throated affectionate applause he had ever earned.

It is a curious situation, as Marchuk observed. Yeltsin has decreed that the academy and its possessions on Russian soil now constitute the Russian academy, but he has not yet decreed a budget for 1992. Before that can be done, there has to be a charter. Last week's three-day meeting was an elaborate process of consultation to that end. The charter, which will be provisional for 1992 , may be amended later by a mechanism not yet defined (but over which the Russian parliament will have a final say). A second three-day meeting, due to end today (19 December) will, among other things, elect a president of the new academy.

The academy's first draft, already full of democratization, is likely to be even fuller after last week. Institute directors are to be elected, and for no more than two terms. Scientific councils at research institutes will also be elected.

Research institutes will have individual charters, defining their objectives and the means by which these may be achieved. The administrative autonomy that research institutes already enjoy to sell products and even capital equipment or land will be confirmed, as will be their freedom to decide on their researchers' salaries. That many at last week's meeting referred to the academy's institutes as "collectives" is natural enough.

Last week, the radicals were also asking for the Moon. One passionate speaker asked that the nascent academy should demand of the Russian government that the budgets for 1992 and 1993 should be identical with that for 1990 , and that there should be no enforced staff reductions. The proposal was considered unrealistic in the circumstances.

The previous weekend's momentous meeting at Minsk and the inevitable consequences of the impending economic reforms (now promised for 2 January) seemed irrelevant. Yet people privately acknowledge that the pace of price inflation will then be so great as to make a nonsense of any budget, and that the government of Russia, in any case, may have no money.

Boris G. Saltikov, the able minister of science in the Russian government (said by some to be too intelligent to survive) had already spelled it out. "If you have enough money, you have freedom." $\mathrm{He}$ promised to provide "a certain minimum" for next year, but warned that the final budget will depend on how well inflation is contained and that "the situation is almost beyond control". In any case, 1992 will be a "period of transition", during which there will have to be a "deep restructuring of science and of the academy". Beyond that, he foresees that Russia will support only the infrastructure of research.

The unreality of last week was illustrated by the issues mentioned but hardly discussed. Should the academy continue to administer directly what it claims to be the most important slice of basic research in Russia? Marchuk is united with the radicals in the belief that separation would be disastrous. Should the academy continue to distance itself from the universities? With stalinism, the case for keeping young people out of reach of free-thinking researchers has also been buried, but the new academy is no more inclined than the old to help the universities. But Saltikov 
may have other ideas.

And what on earth is to happen to industrial research, hitherto mostly the responsibility of research institutes managed by production ministries now swept away? Until industrial plants are privatized, and are able to recruit research groups of their own, Russia's applied research laboratories will have to survive on whatever crumbs of outside contracts they can win in competition with the ever-hungry academy institutes. But the academicians seem indifferent to their fates, as they are to those of the Soviet academies of medicine and agriculture.

And, in any case, can Soviet science in the large survive? Last week's meeting was predicated on the assumption that a democratized academy will continue intact. (At one point in a tortuous debate, the verb "to liberalize" was struck out in favour of "to democratize".) Only Academician L. V. Keldysh, director of the Lebedev Institute, spelled out what disasters may lie ahead if economic reform fails, or is halted by discontent.

But there is general anxiety among researchers about the rate at which able colleagues are leaving for overseas. One amendment to a draft text that would have required the academy to "study and analyse" the causes of emigration was voted down in the belief that the academy should be doing something instead.

Two needs stand out most clearly: there needs to be an office in Moscow (and perhaps in Kiev and Minsk) at which researchers can find out from Western colleagues what help is available from elsewhere, and the Russian academy and government need to make it legally possible for researchers to receive research grants directly, and to spend the money as they choose. The first should be feasible with Western help, but where democratization has not yet gone so far as to allow Russians to live wherever in Russia they choose, the second seems more distant.

Meanwhile, there are some signs of initiative and good cheer. The front runner in the election of a new academy president is Academician Ye. P. Velikhov, director of the Kurchatov Institute with a liberal reputation. And the ingenious director of the International Baikal Research Centre and the Limnological Institute at Irkutsk, Dr Mikhail Grachev, is planning to bottle Baikal water and to sell it at $\$ 2$ a litre as the purest natural water in the world.

John Maddox

\section{Nature index issue}

This unusual weekly issue is Nature's first attempt to produce its elaborate annual index within the year to which it refers. It is hoped that readers will not too seriously miss the regular features omitted to make room for the index. Nature will next appear on 2 January 1992.

\section{DNA fingerprinting discord}

\section{Washington}

THE forensic technique of DNA fingerprinting is again at the centre of a controversy with the publication in tomorrow's issue of Science of an article casting doubt on customary uses of the technique.

The authors of the paper. population geneticists Richard Lewontin from the Museum of Comparative Zoology at Harvard University and Daniel Hartl of Washington University School of Medicine, are neither new to nor shy of controversy. Both have testified in recent court cases against the validity of DNA fingerprinting.

But they are offended that an official of the US Department of Justice asked them to reconsider publication and that the editors of Science have decided to publish a counterattack in tomorrow's issue.

DNA fingerprinting relies on knowing of several short stretches (genetic alleles) of DNA that may differ from one person to another without physiological consequences. In a courtroom, if these pieces of a suspect's DNA match samples found in connection with a crime, a suspect who would otherwise have gone free may be convicted.

The usefulness of the technique rests on reliably identifying several alleles in a DNA sample and proving that this combination is unlikely to be found in anybody else. Lewontin and Hartl challenge the assumption, central to the second task, that the probability of a match between two unrelated persons is the product of the chances that one has inherited each of the several alleles examined. Probabilities as low as one-in-atrillion have been quoted.

Lewontin and Hartl argue that simply because a certain allele appears in only, say, one in 1,000 caucasian men, the chance of a match in all subgroups of caucasian men is not necessarily that low. The same allele might be carried by every member of a suspect's family, for example.

So, Lewontin and Hartl say, if a crime and its suspect come from a small homogeneous community, the chance that a certain allele occurs should be based on data from that subgroup alone. But such data do not generally exist, so it is impossible to calculate the likelihood of misdiagnosis. They conclude that DNA fingerprinting, at least as commonly practised, should be inadmissible evidence.

Science had accepted the paper and set it in type when, in early October, Hartl was telephoned by James Wooley, an assistant US Attorney in the Department of Justice's Organized Crime Strike Force Division in Cleveland, Ohio. Accounts of the conversation differ. Wooley says he expressed surprise that Hartl was going to publish such a paper and that the rest of the conversation concerned the paper's scientific merits. Hartl says Wooley warned him of the "political consequences" of publishing and asked him to reconsider because of the possibly disastrous consequences for future DNA fingerprint-based prosecutions.

In a letter dated 16 October to Wooley, Lewontin accused him of a "very serious breach of ethics", saying that a request by an official in the Department of Justice Criminal Division Strike Force of a private citizen to act against his inclinations amounts to "intimidation".

Wooley, however, defends his approach to Hartl as a necessary part of forensic science, in which law and science are unavoidably mixed. "I've got just as much right to talk about the science as the scientist," he says.

Meanwhile, Daniel Koshland, editor of Science, had heard that news of the paper had triggered controversy at the International Congress of Human Genetics meeting in Washington, DC, and "asked to see it again". Deciding that the "discussion part went beyond the results part", he asked Lewontin to "tone it down", but Lewontin refused, threatening to accuse Science publicly of trying to suppress the paper.

Eventually Hartl and Lewontin agreed on some changes, but Science has also decided to publish a rebuttal by Ranajit Chakraborty, a University of Texas population geneticist and a frequent expert witness for DNA fingerprinting, and Kenneth Kidd, a Yale geneticist.

The rebuttal was recommended by $\mathrm{C}$. Thomas Caskey, a geneticist at Baylor College of Medicine and a member of Science's board of reviewing editors; Caskey is a prominent supporter of DNA fingerprinting who licenses his techniques to Cellmark Diagnostics, one of the largest DNA fingerprinting companies.

He says he was concerned that "publishing defence testimony in a scientific journal" gives it such weight that courts might reopen, perhaps to overturn convictions obtained on the basis of DNA evidence.

Later this week, a National Academy of Science panel on DNA fingerprinting will meet for what is expected to be the last time before its long-awaited report on the subject. A chapter of the report will address the population issues raised by Lewontin and Hartl, based on an earlier draft of the Lewontin and Hartl paper.

Christopher Anderson 